\title{
How Communicative Language Teaching (CLT) Is Being Used In Kurdistan?
}

\author{
Noora Mohammed Ahmed \\ Dept. of Special Education, Collage of Basic Education, University of Duhok, Kurdistan \\ Region - Iraq \\ Email: Noora.ahmed@uod.ac
}

\begin{abstract}
Learning a language throughout a communicative approach is believed to be more effective as a procedure of teaching a foreign language such as English language. It is believed that the communicative approach assists learners to learn a language successfully by having them to communicate the real meaning. In Kurdistan, schools relay a lot on CLT (Communicative Language Teaching) method as a new and effective way of teaching languages. Through this research, it has been advised to see CLT as an approach for teaching English as a Foreign language (EFL) in Kurdistan rather than as a method. In the current sunrise textbook that is being taught in Kurdistan schools are not merely CLT method based textbook but are a mixture of different communicative approaches which are seen in the examined activities in section Three. Overall, the textbook introduces English as a communicative mechanism to be used inside and outside the classroom with confidence in many aspects of life and give teachers an opportunity to try different teaching approaches that suits their students' understanding, motivation, and communication with the target language.
\end{abstract}

Keywords: Communicative Language Learning (CLT), approach, method, Kurdistan, sunrise. 


\begin{tabular}{|c|c|c|c|}
\hline ond & 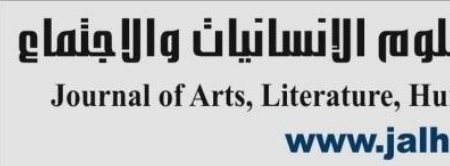 & 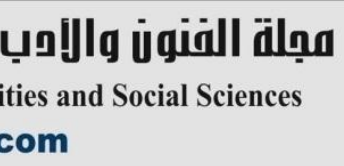 & \\
\hline$=$ & Volume (75) January 2022 & العدد ( 75) يناير 2022 & \\
\hline
\end{tabular}

\section{SECTION ONE: INTRODUCTION}

\subsection{Introduction}

The necessity for communication in English has created many claims of teaching skills. An English teacher plays a significant role in teaching English language in all grades. When teaching a language, teachers have to follow a certain method. There are five approaches in teaching English language such as, Grammar Translation Method, Audio Lingual Method, Direct Method, Situational Language Teaching and Communicative Language Teaching (CLT).

Between all, CLT is one of the new methods. This new approach has identified and arranged what the roles are for the teacher when he/she teaches using this method and what the students' role are in learning by using this method. In addition to the activities and procedures that can be considered to teach positively in the class.

In Kurdistan, CLT has been applied at the end of 1990s with the use of new syllabus for English language that aims to create a communicative environment and fun for both the teacher and students. Moreover, it aims to enhance the students' skills and grammar to be more productive by the end of the school year.

The content of the syllabus is identified as a communicative competence, each lesson of the units includes the four skills and grammatical rules with communicative activities to practice their language. Teachers tried to enrol in teacher training courses to be able to understand and have new techniques and procedures to present the language in a communicative way.

\subsection{Aim of the Study}

The aim of this study is to find out if CLT is being used in Kurdistan and how it is being used. Firstly, the history of CLT with the definitions of CLT will be provided. Secondly, the aims and goals of CLT with the teacher and students' role in CLT will be explained and discussed. The teachers' procedures and classroom activities will be explained as well. At the end, an introduction of CLT with the syllabus and textbook in Kurdistan will be highlighted and investigated on.

\section{SECTION TWO: LITREATURE REVIEW}

\subsection{Background on CLT}

The history of CLT is not as the same as other teaching techniques. It developed in Europe in the $20^{\text {th }}$ century. CLT has been applied for approximately three decades in Europe and some other western countries. CLT was the output of educationalist and linguists who were not satisfied previously with audio-lingual and grammar translation methods, where the students did not learn an effective language that might help them to communicate with each other (Canale and Swain, 1980). Hence, they became interested in the development of communicative pattern teaching in the 1970s with an emphasis on original language use and classroom transactions where students participate in a real communicative language between each other (ibid).

Richards (2006, P. 6) classifies the movements of language teaching in the last 50 years into three stages: 


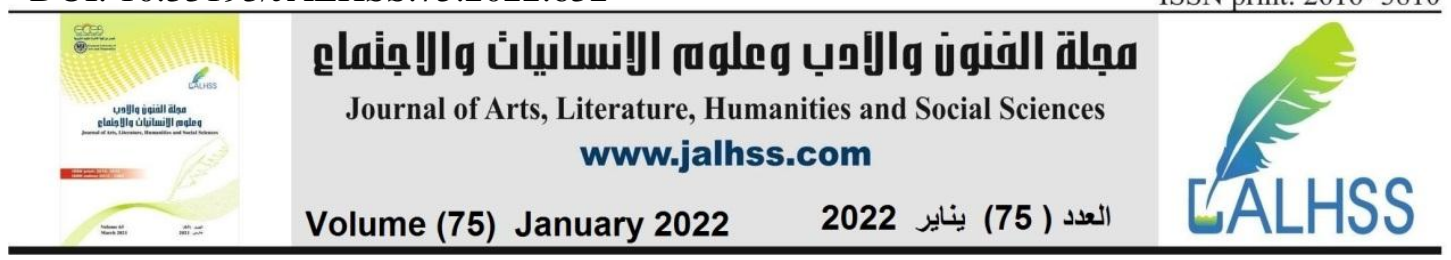

Stage 1: traditional methods (up to the late 1960s)

Stage 2: classic communicative language teaching (late 1970s to 1990s)

Stage 3: current communicative language teaching (late 1990s to the present)

In terms of traditional methods, communicative language teaching (CLT) aroused from the variations in the British conditional language teaching method dating back to the late 1960s (Richards \& Rodgers, 2001). CLT consider the notion of communicative competence as the key concept of language learning. Communicative competence represents knowing what to say and how to say it properly according to the situation, the role and intention of the speaker. Teaching method with traditional vocabulary and grammar are not included in this notion.

Communicative competence was first presented by Hymes in the middle of 1960s, and a lot of researchers have assisted in the development of theories and practices of CLT method. The American linguist Noam Chomsky criticized the lack of view of the behaviourist motivation response of language and language learning held by Skinner (Savigon, 1987). Chomsky debates that the theory of linguistic forms was not enough to explain the principal features of languages, the innovation and exceptionality of individual phrases. Chomsky pointed out that focusing on the concrete language performance, there is an abstract rule in the system and this potential knowledge of the grammar of the mother tongue language is his linguistic competence (Savignon, 1987). On the contrary, Hymes (1968) states that as well as to linguistic competence, the native speakers have a different system of rules. In Hymes' perspective, language is a cognitive and social phenomenon, syntax and language models were understood not as independent, contextual body, but as a useful resource used specially in traditional means and developed by the social communication and absorption of others speech (ibid).

Therefore, language speakers need to have more than grammatical competence to be able to interact efficiently in a language. Also, they require knowing how language is used by the community of the native speakers to achieve their aims (Hymes, 1968). While, researchers were different in many ways, they all underlined the importance of communication. Therefore, Hymes (1971) presented the term communicative competence which indicates the language use in social content. Meanwhile, British applied linguists concentrated on another basic language feature with the functional and communicative possibilities of language that was sufficiently addressed in theories of language teaching during 1980s. Highlighting on the work of functional linguists, philosopher and American Socio-linguists, British applied linguists' state that language teaching requires concentrating on communicative proficiency instead of just focusing on mastering the structures (Littlewood, 1981).

During the 1970s in Europe, the number of foreign workers and immigrants increased because of the growing interdependence of European countries. This state leads the Europe Council to set syllabus for learners depending on the concept of function and notion of language use. In this syllabus, the language ability level was identified for all European languages in term of what students can do with language (Van EK, 1975). Since its establishment as basically a British creation, CLT has extended in scope and now is used extensively as one of the most notable language teaching 


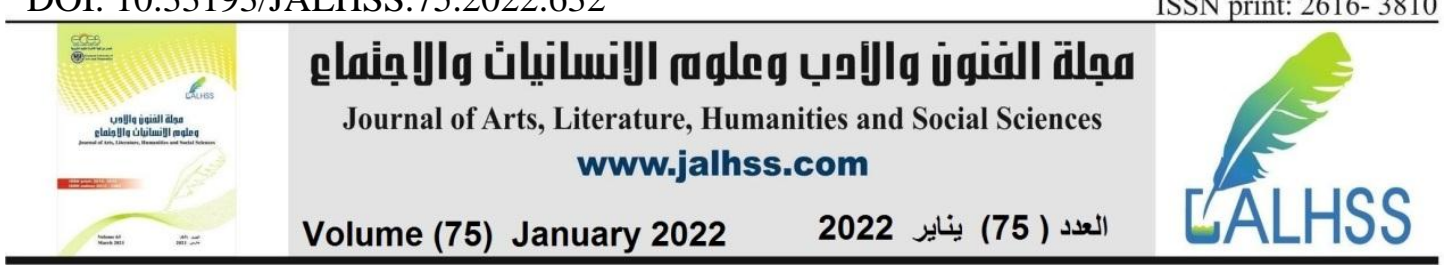

methods in the world. Despite the clarity of its popularity, many teachers are still to a certain extent confused of what CLT exactly is. The next subsection will concentrate on some definitions on CLT and how CLT is being defined by some researchers.

\subsection{Definitions on CLT}

There is a broad debate about the appropriate means of defining CLT and no single form of CLT is globally accepted as reliable (McGroaty, 1984). Yet, regarding to Richards and Rogers (2001), CLT indicates to a variety of principles that reflect a communicative perspective of language and language learning that can be used to support a wide range of classroom measures. It also refers to the Symantec interest to function and the structural aspect of language and grouping these into a more complete communicative view (Littlewood, 1981).

In addition, CLT implies to be capable of using the language efficiently in a communicative context. Communicative competence points to the capability to use language suitably in various circumstances (Mitchell, 1988). CLT indicates that the impact is on the use of language rather than the structure of the language. It largely focuses on the spoken context of English. Although, speaking is a vital part, reading, writing and listening skills are highlighted as well. Practicing on speaking, intonation and stress is an important element because language is focused on real life circumstances. Therefore, the communicative competence of the students is objective, instead of linguistic competence (Melrose, 1991).

CLT benefits from daily life situation which require communication. This is similar to the functional notional approach which combines two important components, meaning and communication which present a range of grammatical rules and vocabulary that the students use in everyday life and taught communicatively in a way that they can perform the language and master the grammar too. Dislike the audiolingual approach of language teaching, that depend on repetition and drills, the communicative approach promotes learners and encourage them to use their new information outside the class as an outcome according to their reactions and responses. As the real-life stimulation varies every day, students' motivation to learn comes from their willingness to communicate and interact in meaningful ways about meaningful subjects. From the definitions above, it can be presumed that CLT means to teach a language in a way that learners can be able to communicate with other people globally.

\subsection{The aims and goals of CLT}

Each method has some aims and goals. For instance, the aim of Grammar Translation Method (GTM) is to learn a language by translation. The aim of Direct Method (DM) is to learn a language directly with the assistance of the teacher. On the other hand, the aim of CLT is to learn a language in a communicative way i.e., to become communicatively competence (Mitchell, 1988). Communicative competence includes the ability to use language properly to the given social context. The teacher is the facilitator of students learning and the most visible feature is that almost anything 


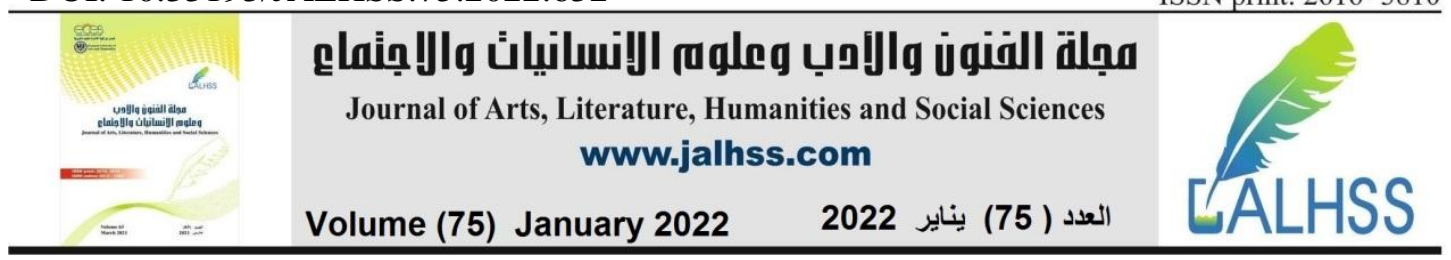

presented in the classroom is need to be done with communicative purposes (Freeman, 1986).

CLT aims to help students overcome mastering the structures in foreign language to the point where the structures can be used to communicate usefully in everyday situations. this suggest that people who are learning English language are those who wanted to be able to communicate socially every day with the native speakers or nonnative like speakers who are able to pronounce English language very well (Mitchell,1988). Also, some people learn English language to be able to live in or visit a foreign country normally with no language obstacles.

The basic goal of any foreign language teaching has been the ability to communicate effectively, and this is broadly used in CLT method. Nevertheless, the effects of this goal have been carefully studied since 1970s. The communicative approach makes the teacher and the students consider that learning a language can be taught in terms of functions performed by communication in real situations, with the grammar and vocabulary (Skehan, 1996).

In fact, the goal and aim of CLT is to make the communicative competence the goal of language teaching and to develop ways for the purpose of teaching the four language skills (reading, writing, listening, and speaking) that recognize the interdependence of communication and language (Howatt, 1984). In contrast to the audio-lingual approach, the main concern of CLT is to help the learners to create meaning instead of helping them develop grammatical structures ideally or obtaining native like pronunciation.

This signifies that learning a foreign language successfully is evaluated by how good students have developed their communicative competence, which can be determined loosely as their ability to imply knowledge of formal and sociolinguistics notion of language with efficiency to communicate.

\subsection{The teachers and students' role in CLT}

The learner-cantered feature of Communicative language teaching and the new kind of class activities, involves various roles in the language classroom for teachers and students than those roles which found more in second language traditional classes. Learners in CLT classes are assumed to take part in class activities that are based on a cooperative approach instead of individual approach in learning. They are shown as inactive participant in the process of language learning, therefore, CLT changes the role of the teacher. Also, CLT has a lot to do with communication as well. Accordingly, it may be wise to claim that the role of teacher and students in CLT classes has a vital characteristic, and therefore, they tend to differ every time.

Breen and Candlin (1980), in identifying the teacher's role in CLT classrooms observed that the first role is the facilitation of the process of communication among the whole participants in the class, also among the different materials (activities and texts). The second role of the teacher is behaving as an independent participant in the set of teaching and learning process (ibid). The final role of the teacher is that the teacher is a learner and a researcher, with a lot of contribution in terms of appropriate knowledge, capabilities, effectiveness, and monitored experiences of the learning nature and organized capabilities (ibid). This calls attention to the characteristic of 


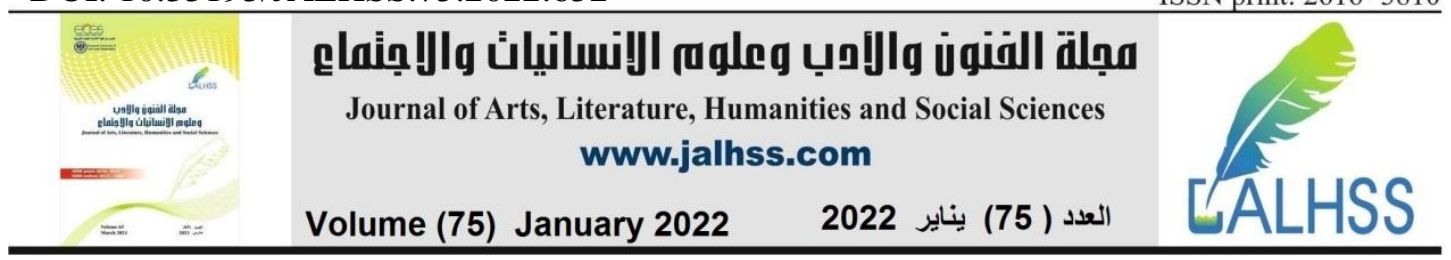

CLT that the learner-centred approach is based on the experience as a second language learning (Richards and Rodgers, 1986).

Therefore, it is recommended for teachers to adopt a communicative approach to produce and use original teaching materials and subjects that address the special needs of learners. Moreover, teachers are required to stimulate their students, also to provide them with a convenient atmosphere in the classroom for language learning. Littlewood (1981) claims that the teachers' role in CLT consist of, coordinator and director of activities, language teacher, a source of a new language, advisor when necessary, also a participant, but not limited to these roles only.

Furthermore, it is common in CLT classroom that not just the teacher manages the classroom, but all the attendances manage the performance of the classroom (teacher and students). Breen (2001) believes that teachers are no longer being considered as just teachers and learners are learners only, since both of them are administrators of learning. The classical picture of the teacher as a figure of dominating power in the classroom have been solved in to such a role that requires facilitating the interaction and communication process in the classroom where the students feel safe and not defensive (ibid). Moreover, $\mathrm{Hu}$ (2002) suggested that the students' role in CLT classes is assumed to be negotiators of meaning, explorers and participants in knowledge and information.

Moreover, Savigon (1987) in her description of the teacher's role and students in CLT classroom, she stressed that students are strongly participate in communication and negotiation of meaning while the teacher takes over the role of a participator and a facilitator in language classroom.

On the other hand, Deckert (2004), refers to the student-centred features and confirms that CLT views a low characteristic of the teachers' roles, continuously with pair work or small group problem-solving, students respond to real samples of English by expanding and exchanging on every useful topic with the integration between the four main skills which they are reading, writing, speaking, and listening. Beside this, a class through a communicative activity is further far than quite, however, the students do most of the talking (speaking) and the classroom is always vital during the communicative activities and exercises also, students are more capable of managing their own language (Freeman, 1986).

To sum up, it can be said that CLT is concentrating mainly on the students' role by focusing on the how the student can learn a language in a communicative way and not concentrating on the teachers' roles in directing the class communicatively by providing techniques and procedure that can help the teacher to provide and facilitate a communicative atmosphere for the learners to play their roles effectively. This will lead us to the next subsection to find out the teaching procedures and activates that CLT presents for a communicative classroom.

\subsection{Teaching Procedures and Classroom Activities}

As shown previously, the success of CLT based largely on the procedures of teaching and classroom activities. If the teachers do not provide the suitable activities in the classroom, students will not get advantage from CLT method but they will feel uncomfortable and easy get bored. The teachers should take these activities into 


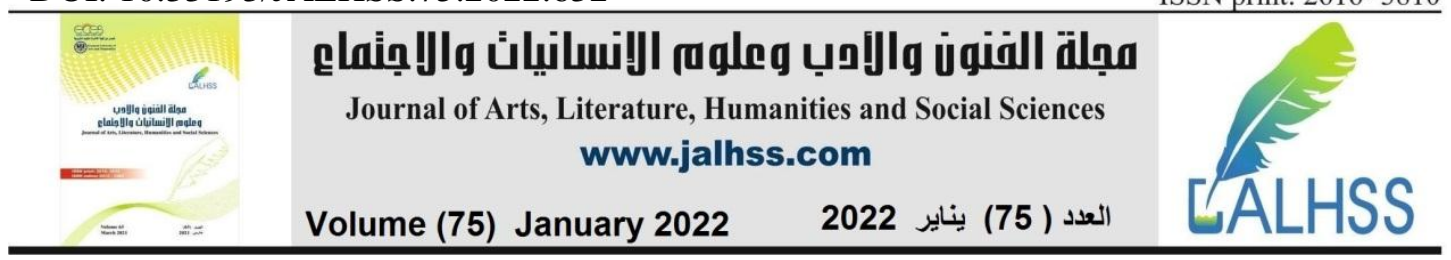

consideration before attending the classroom. Nevertheless, CLT is a general approach requires the use of exercises in the classroom in any kind of methodological way. Different types of activities may be used in the classroom like, a role play, interviews, multiple choice, games and group work. However, not all teachers will limit their activities to these. Some classes may have the students to take a grammar test or doing homework at home (Canale and Swain, 1980).

Through the appearance of CLT, teachers and material designers tried to find out ways of improving classroom activities that includes the principles of CLT and still continuing until the present day. Hence, there are many types of activities that considers as an outcome of CLT approach such as, accuracy and fluency activities, information-gap activities, jig-saw activities, task-completion activities, informationtransfer activities and opinion-sharing activities. The following activity is an example of jig-saw activities:

The teacher plays a recording in which three people discussing their opinions on a topic. The teacher divides students in to three groups (A, B, C) and each group listen and takes notes on one of the three people's opinion. After that, the groups are rearranged again including a student from $\mathrm{A}, \mathrm{B}$, and $\mathrm{C}$ groups. Now they role play the discussion by using the information they reached. The teacher divides the discussion in to as many sections as there are students in the class so that every student gets one section of the discussion. While listening to the discussion again, students will move around the class to see where their section fits in the discussion. Finally, students are required to arrange the whole discussion again in the correct order.

In my opinion, choosing activities depend on the teacher and how she/he will explain the activity in order to be taught communicatively and creating some new activities that might help the students to strengthen the weak areas in their learning. The syllabuses that are designed as a communicative approach are considered to consist of communicative activities and exercises that help the student to learn communicatively. In order to find out if the syllabuses of CLT consists of communicative activities or not, the upcoming section will focus on textbook investigation. However, not all the syllabuses that are assumed to teach communicatively are a purely a CLT syllabus. In the upcoming section, a certain syllabus in Kurdistan will be investigated on.

\section{SECTION THREE: TEXTBOOK INVISTIGATION}

\subsection{CLT in Kurdistan}

Currently, English language is used in many countries in the world as a first or second language, but as Kurdistan is a bilingual country, English is considered as foreign language. People learn English language to be able to speak with the people from other countries, to improve their job prospects and have job opportunities outside their countries. The need and necessity for learning English is growing day after day, and English is presented as a compulsory subject on the school curriculum from kindergarten to junior high level. The students of Kurdistan are required to study English as one subject. However, most of the students in Kurdistan are not able to use 


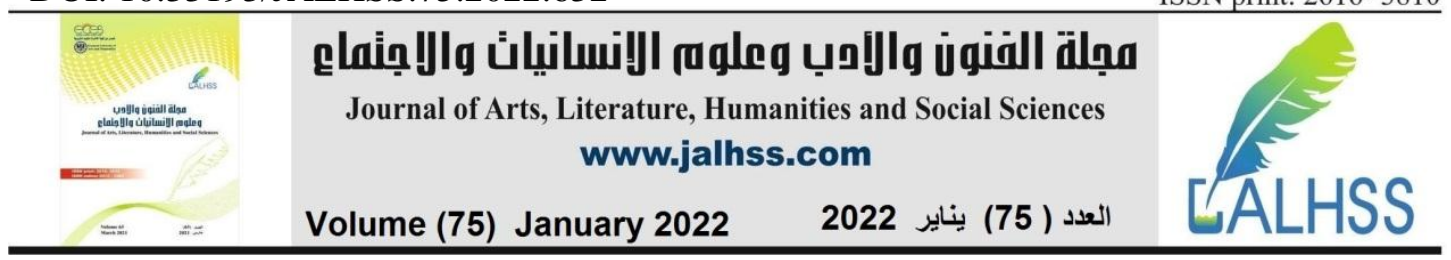

English language in a practical way in different situations. This is because one of the methods that are used in Kurdistan was Grammar Translation Method and for many years students learnt English by translation and memorization with using and explaining only grammar rules which let the students fail and dislike learning English language. As a consequence, CLT was adopted in Kurdistan towards the end of 1990s.

The aim of this method is to develop the learners' communicative competence in the four skills. It is also a method that is recently being applied in Kurdistan in all the levels of public schools, but the textbooks of this approach were a source of frustration to the teachers at high school levels as they had not been trained how CLT is being applied nor briefed on using such textbooks (Ministry of Education, 2011). Then the Ministry of Education opened summer teacher training courses for the teachers aimed at providing them the knowledge and understanding of CLT and to make them realize the chances they could exercise in using the textbook. They figured out that their duty was not only to finish the book but to select supplementary sections or subjects depending on what kind of activity the teacher wanted to practice for the students (ibid).

The communicative approach is broadly accepted for teaching EFL in Kurdistan. Teachers now believe that the situation of teaching English can be raised if we rely on this approach in language teaching. The students have accepted their positive roles in the classroom where the traditional method of the teachers giving lessons is still performed. The goal is to make learners achieve the required knowledge and to allow them express what they want by using the authentic language. The implication of the communicative approach may be done through frequent practice of the language Also, the teacher should have enough knowledge and information of the method that he/she use to create student's self-confidence in learning and using the language. In addition to that, the teacher should allow students to express their ideas and experiences about learning the language. Yet, this is the teacher's responsibility to motivate and stimulate students to create a positive attitude about the language and encourage them to learn the language instead of demotivating students toward language learning. Only then CLT would be efficient for the students.

Taking everything into account, CLT has been adopted as a method in language learning and the process of learning has been changed, thus, there is no doubt that the syllabus has been changed too. In the next subsection the syllabus in Kurdistan will be presented.

\subsection{Syllabus in Kurdistan}

Textbooks play a vital role in the process of teaching and learning. The users of the school curriculum are the teachers and the students. In Kurdistan, the syllabuses have been changed continuously in order to find a method that can be effective for the students. It has been noticed recently that the level of the students were dropping significantly, therefore, in 2005 the ministry of education took an important step to improve the education standards of teaching English language by designing a new curriculum with the help of the British company (Macmillan) which produced a new curriculum for teaching English language in Kurdistan known as Sunrise. 


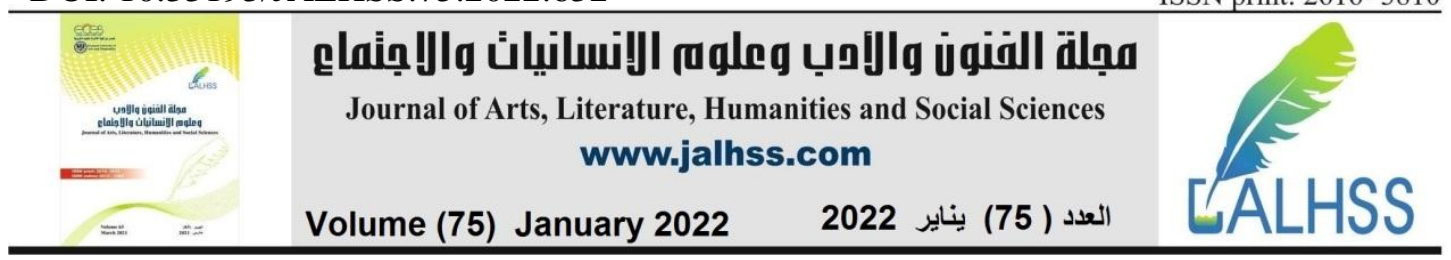

The new Sunrise syllabus has been produced by several technical experts of CLT and other educators with the latest European methods of teaching in United Kingdom, London (Ministry of Education, n. d.). Sunrise is a complete English textbook written particularly for primary and secondary school students (ibid). The syllabus has a communicative approach combining the four skills (listening, reading, writing and speaking) with an obvious focus on grammar structures (ibid). It can be considered as a PPP (Present, Practice, and Produce) method because a new grammar structure presented through a short conversation or dialogue. After explaining the new structure by the teacher, the students practice the new structure during exercises. Finally, the students use their own information to practice the new structure through speaking.

Sunrise aims at developing English during a fun and useful method in learning, using exiting and adventure stories that motivate the students to learn a new language with different kinds of activities such as, role play and writing task-oriented (ibid). The new syllabus consists of two textbooks (student's book and activity book) with audio $\mathrm{CD}$ for the students and a textbook (teacher's book) for the teacher.

In my teacher training course, I taught level seven students which they were using Sunrise syllabus for their language learning. The textbooks seemed a communicative approach consists of lots of activities that make students interact and be more active also the teacher's book gives significant guidelines on how to teach the textbook in a communicative environment. In the next subsection, an investigation of the textbooks will be highlighted.

\subsection{Textbook Investigation}

When textbooks are handed out to the students, they must attract their attention so they should be colourful and eye-catching, so they are instantly keen to find out what lies under the covers. In order to know if the new textbook Sunrise contains communicative materials and lessons that make the students use the four skills with grammar basic rules and whether it develop the communicative competence in language learning, the level seven English textbook will be investigated on.

Sunrise level seven is the first grade for high school students, produced and designed to continue on their primary school English and develop confident learners of English language. The key features of the textbook consist of:

-Makes learning fun through motivating topic-based units. Each unit has a review lesson at the end to recycle and reinforce language.

-Has a clear and comprehensive grammar syllabus.

-Has a story running through the book, with young characters who introduce new language.

-Has dramatized dialogues for students to act out and practise real language.

-Has a CD with dialogues and sound files to practise pronunciation and intonation.

-Has an adventure story at the end for intensive reading practice.

-The activity book provides consolidation and practice of grammar and vocabulary. (Mclver, et al., 1999, P. 118).

The students' book includes a welcome unit, seven units and each unit has four lessons with different topics plus a review lesson. Moreover, at the back there is a fare well unit, grammar summary with translation and a word list. Activity book 


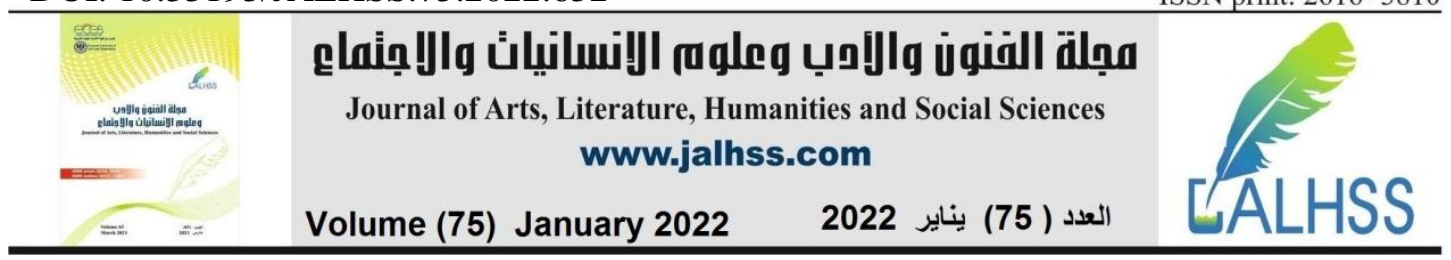

provides examples and questions from the student unit's book to answer them and practice. The topics that are covered in the student's book chapters are, people and places, things, sports, animals, time and space, free time, and a long time ago. It appears that the textbook subjects meet the learner's need because the students became more interested in learning English language and engaged them with the different activities that allow them to communicate with each other.

In Unit Three of the level seven, sport activities are presented, and the topics provided in this unit are: she's touching her toes, she's on the left on line 3, whose seat is this, this is a nice photo. Every lesson is provided by an interview (see appendix 2) which includes grammar structure and vocabulary of the lesson for about 5 minute which requires listening and reading. The grammar file which introduces and explain grammatical rules also the grammar rules that is covered in this unit are; present continuous: positive, preposition of place, possessive ('s) and possessive pronouns. Moreover, the rules are implicit to a certain extent because grammar rules are not being used in all the activities In addition to a game such as, the face game (see appendix 2) which the students play to practice their pronunciation, grammar rules and vocabulary Such as hair, ear, nose, teeth, mouth, and eye. And this leads to develop the students' fluency to express themselves in a better way.

Reading is also a part in each lesson along with writing and sound file. The writing activity (write about yourself (see appendix 2)) can be taught communicatively. For instance, each student writes the description of his appearance and how he/she look on a stick paper then put all the papers together later each student selects one paper and read it loudly then all the students will try to find who is he/she. After each lesson finish, the teacher gives some homework to the students from the activity book such as, students need to ask a member of their family about what he/she like and dislike (hobbies, foods, sports) then they write it in their notebook. If they did not know the English word, they have to ask in the next lesson when they share it with their classmates. Furthermore, all the lessons that are introduced in the units are based on everyday conversation and communication.

The teacher's book gives complete explanation on how to write your daily lesson plan for producing a communicative environment for the students to be able to interact in the lesson in a positive way. Moreover, the teacher's book demonstrates how to present the information given in the text book with many techniques and procedures to help the teacher to give effective information based on a communicative competence. Nevertheless, the teacher's book is only a guideline for the teachers and they should not depend on it also the teachers should be creative to find communicative ways in order to teach effectively. Moreover, the method that is being used by the teachers should be learner-centred not teacher or textbook-centred.

However, there are some drawbacks in the student's book that makes it not to be a truly based on a CLT method because there is no dialogue that the students can speak and practice; in other words, there is no daily life conversation dialogue that they can practice in the class. Also, the face game is a total physical response (TPR) activity because they use the body language to learn the vocabulary. In addition, the pictures do not match the topic of the subject so that the students can describe them (see 


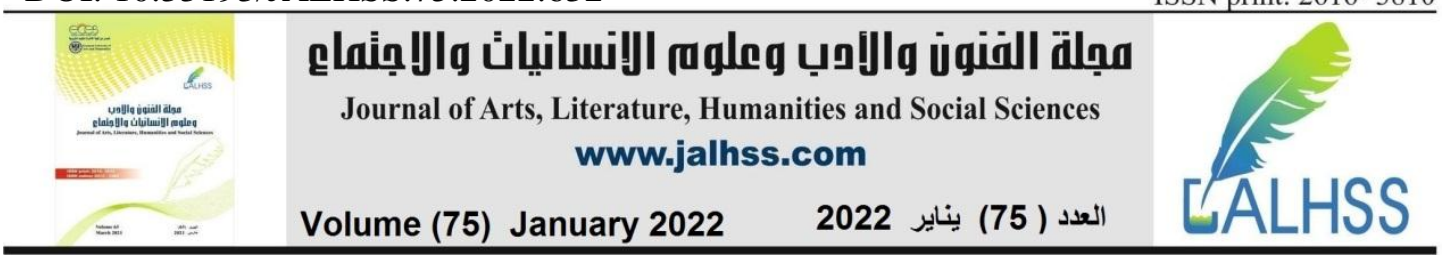

appendix 2). Also, the map of the student's book (see appendix 1) is arranged as structure first, then skills and sound, then vocabulary. This is means that it is near to a PPP method rather than CLT because they still concentrating on the structure first.

It can be seen that the new syllabus that is now being used in Kurdistan is a combination of methods which make this textbook not designed to be a CLT textbook. In addition to that, the syllabus designers assumed that sunrise has a communicative approach, but the activities show the opposite; they view a combination of different methods that is gathered in this textbook. However, apart from the textbook some teachers cannot teach students as they should be taught because of the lack of sound laboratory in some schools also of the teachers' weak pronunciation and explaining most of the lesson using first language.

\section{SECTION FOUR: CONCLUSTION}

\subsection{Conclusion}

CLT is better to be regarded as an approach instead of a method. It indicates to a various range of principles which signify a communicative perspective of language and language learning which might be applied to assist a broad diversity of classroom procedures (Richards \& Rodgers, 2001). CLT as a way of teaching EFL appears to be important in Kurdistan; it seems that the new textbooks that are currently being used in schools are not a CLT method, so it seems that the textbooks that I thought it is CLT, they are not only CLT but they are also a combination of methods such as, PPP (Presentation, Practice, Production) and TPR (Total Physical Response).

With regard to how it is being used, it can be said that the activities that are considered a CLT activity, are being taught depending on the teacher and how he/she presents the activities in the class. Yet, there is more space for individual interaction and variation in the activities in each lesson that leads to be important in terms of syllabus design. Moreover, the sunrise textbook develops students' awareness of English language to be confident in using the language in the classroom and outside the classroom too. Not to forget, it also helps teachers to use a new approach for enhancing their teaching and increase the success rate.

\section{References}

1. Canale, M. and Swain, M. (1980). Theoretical Bases of Communicative Approaches to Second Language Teaching and Testing. Applied Linguistics 1:1: 147.

2. Deckert, G. (2004). The Communicative Approach: addressing frequent failure. English teaching Forum 42:1: 12-17.

3. Hu, G. (2002). Potential Cultural Resistance to Pedagogical Imports: the case of communicative language teaching in China. Language, Culture and Curriculum 15:2: 93-104.

4. Hymes, D. (1971). Competence and Performance in Linguistic Theory. In Huxley, R. and Ingram, E. (eds.) 1971. Language Acquisition: Models and Methods. London: Academic Press. 3-28. 


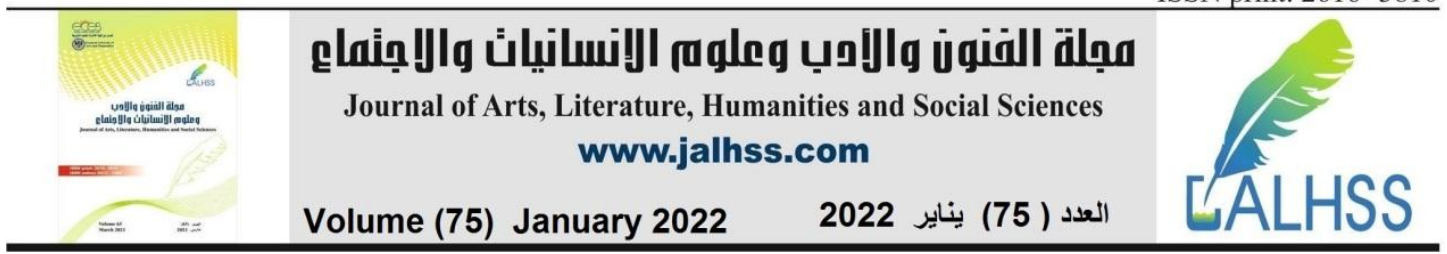

5. Howatt, A. (1984). A History of English Language Teaching. Oxford: Oxford University Press.

6. Littlewood, W. (1981). Communicative Language Teaching: An introduction. Cambridge: Cambridge University Press.

7. Larsen-freeman, D. (1986). Techniques and Principles in Language Teaching. Oxford: oxford university press.

8. McGroarty, M. (1984). Some Meanings of Communicative Competence for Second Language Students. TESOL Quarterly 18:2: 257-272.

9. Melrose, R. (1991). The Communicative Syllabus. England: British Library Cataloguing in Publication Data.

10. Mclver, N., Prowse, Ph., and Garton-Sprenger, J. (1999). Sunrise Student's book. Oxford: Macmillan Publishers Limited.

11. Mitchell, R. (1988). Communicative Language Teaching in Practice. Warwick: Centre for Information on Language Teaching and Researching.

12. Ministry of Education, (2011). Xola Sheyandina Mamostayan. Kurdistan: materials for teacher training.

13. Richard, J. and Rogers T. (2001). Approaches and Methods in Language Teaching. Cambridge: Cambridge university press.

14. Richards, J. (2006). Communicative Language Teaching Today. New York: Cambridge University Press.

15. Savignon, S. (1987). Communicative Language Teaching. Theory into Practice 26:4: 235-242.

16. Skehan, P. (1996). Second Language Acquisition Research and Task-Based Instruction. In Willis, J. and Willis, D. (eds.) 1996. Challenge and change in language teaching. Oxford: Heinemann. 17-30.

17. Ministry of Education. (n.d). Class resources. n. p. :Macmillan. [online]. Available from <www.sunrisekurdistan.com> [10 Dec 2011].

18. Van Ek, J. (1975). Systems Development in Adult Language Learning: the threshold level in a European unit credit system for modern language learning by adults. Strasbourg: Council of Europe. 


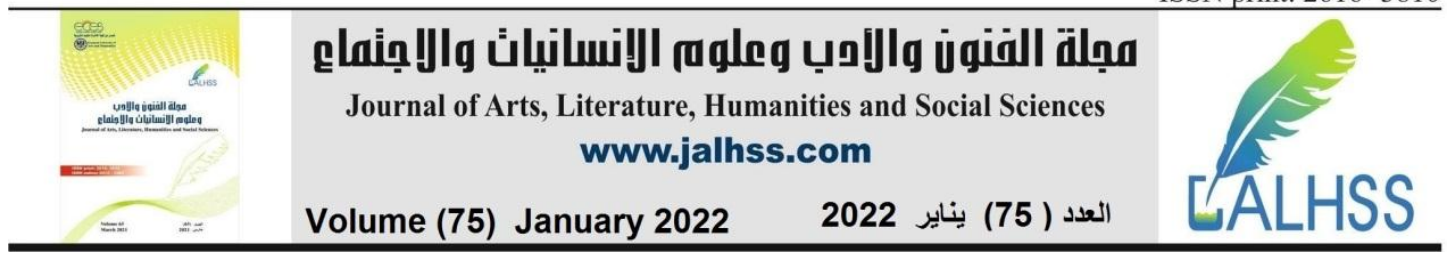

\title{
APPENDICES Appendix 1:
}

MAP OF THE BOOK WELCOME UNIT

1 Hello I'm...; What's your name? How old...? Where...?; to be; he, she, we, they; countries and nationalities; instructions

2 What's this? What's this? It's a lan... instructions

3 It's my notebook. Numbers $0-10 ;$ you, my, your; preposition: in; classroom items; alphabet

4 What time is it, please? Numbers 11-20; o'clock, half past; this/that

5 What's your favourite sport? What's your favourite ...?; Is it ...?; Yes, it is. No, it isn't; sport; colours; imperatives

6 Her T-shirt is yellow Possessive adjectives; countries and nationalities; clothes; plural nouns

7 Is Steven her brother? Family; to be: questions and negatives; numbers 21-100; I think...

8 What day is it today? Days of the week; When...? time; prepositions: on, at; school subjects

\section{UNIT 1 PEOPLE AND PLACES}

\section{STRUCTURES}

Present simple to be; questions: what? personal pronouns; possessive adjectives

Present simple to be: questions, short

Present simple: positive; like, love, hate, live, speak

4 Ist, 2nd, 3rd, 4th; question: when?

REVIEW of unit language; song:WYG song UNIT 2 THINGS

\section{STRUCTURES}

Present simple: negative, questions and

short answers; or, but

2 have got: positive and negative; $a$, some, any

3 have got: questions and short answers;

\begin{abstract}
Can I ...? (requests and permission); pronoun: one
\end{abstract}

\section{SKILLS}

Syllable stress in numbers: $13 / 30$

Reading/Writing: personal profile

Listening: numbers and dates

Speaking: personal information

To help you study: learning words:

vocabulary notebook
VOCABULARY

Personal information;

Countries; numbers $21-1000$

Languages

Ordinal numbers; months and dates

\section{(n)}

ThILLS AND SOUNOS

\section{SKILLS AND SOUNDS \\ /s/ with plural nouns}

Contrastive stress

Listening/Speaking: conversation

Listening/Speaking: conversation
Reading/Writing: personal letter

To help you study: classroom English

vocabulary notebook

REVIEW of unit language; song: $M y$ favourite things

U NIT 3 SPORT
S STRUCTURES
1 Present continuous: positive
2 There is/are; prepositions of place: in, on
3 Possessive 's; possessive pronouns;
4 question: whose? let's ...

REVIEW of unit language; song: Body Rap
SKILLS AND SOUNDS

Silent letters

Syllable stress: two syllable words

Listening: descriptions of people Speaking: describing people Speaking: describing people
Reading/Writing: postcards Reading/Writing: postcards
To help you study: ways of learning vocabulary notebook
VOCABULARY

Parts of the body; verbs for actions

Furniture and equipment: verbs for actions Possessions

Verbs for actions

\section{STRUCTURES}

Can (ability)

2 Present continuous: questions and negative

3 Comparative adjectives: -er; better, worse; than

REVIEW of unit language; song: Do the monkey!

\section{SKILLS AND SOUNDS}

Pronunciation of $i$

Reading/Listening: descriptions of animals Speaking/Writing: describing animals To help you study: classroom English vocabulary notebook
VOCABULARY Pets; skills and abilities Zoo animals Adjectives

Wild animals; continents: measurements 


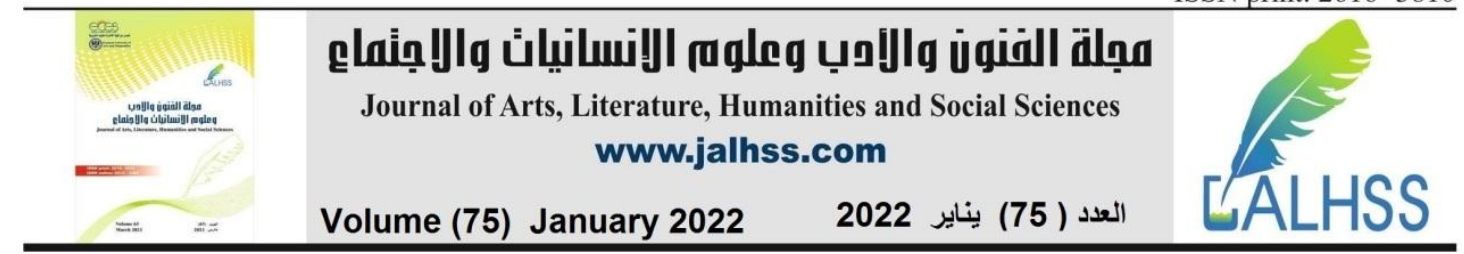

UNIT 5 TIME A N D SPACE
STRUCTURES
Prepositions of time: at, in, from ... to; present
simple: routines; adverb of frequency; usually
2 Present simple: routines; present continuous: now
3 Is / Are there ...? and short answers; question:
How many? prepositions of place: next to,
near, opposite

REVIEW of unit language; song: Space Talk

UNIT 6 FREE TIME
STRUCTURES
would like + noun/infinitive; that/those;
countable and uncountable nouns
2 like, love, hate +-ing; good at +-ing
3 Comparative adjectives: more + adjective;
4 questions: How much ...?, Which one ...?

REVIEW of unit language. song. Come and dance with me!

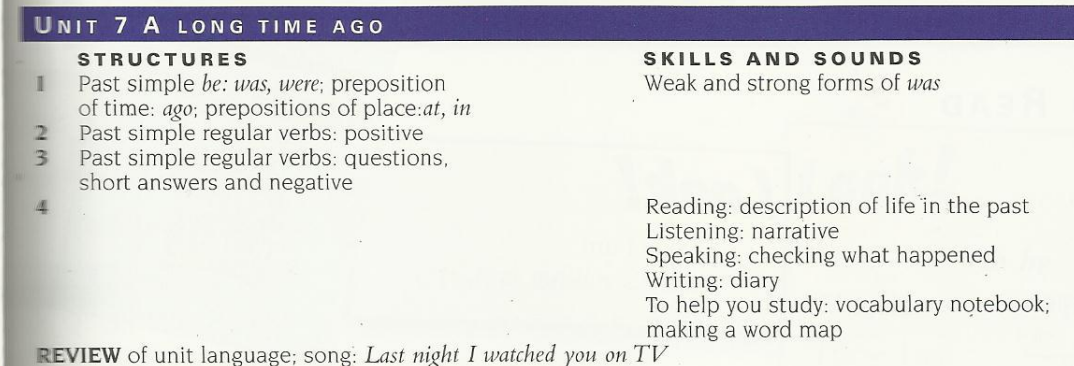

SKILLS A N D S O U N D S
Stress timing
Syllable stress: three syllable words
Reading: visitor's information and map
Speaking: asking for and giving information
Listening: opening and closing times
Writing: giving information about a place
To help you study: vocabulary notebook

VOCABULARI

Time-telling; routine actions

Verbs for actions

Rooms, furniture and equipment

Town facilities

\begin{tabular}{|c|c|}
\hline & P 70 \\
\hline $\begin{array}{l}\text { SKILLS A ND SOUNDS } \\
\text { Syllable stress: three syllable words }\end{array}$ & $\begin{array}{l}\text { V O CA B U LA R Y } \\
\text { Food and drink }\end{array}$ \\
\hline Syllable stress: three syllable words & Sport and leisure activities; \\
\hline & $\begin{array}{l}\text { Shopping and prices; } \\
\text { longer adjectives }\end{array}$ \\
\hline $\begin{array}{l}\text { Reading/Writing: personal profile } \\
\text { Listening/Speaking: interview } \\
\text { To help you study: ways of learning. }\end{array}$ & $\begin{array}{l}\text { Favourite things and activities; } \\
\text { classroom English }\end{array}$ \\
\hline
\end{tabular}

eaking. interview

To help you study: ways of learning;

classroom English

self assessment

\section{Farewell UNit GoOdBYE From LONdON}

REVIEW of unit language; song: Friends

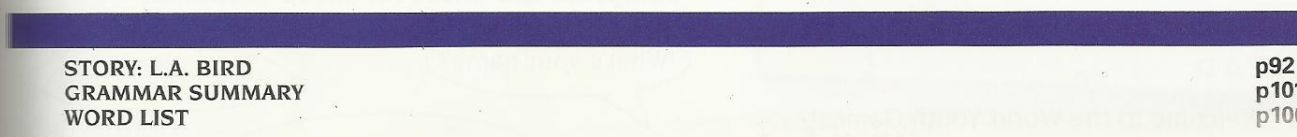




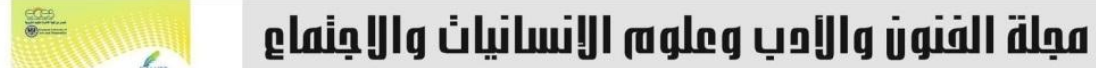

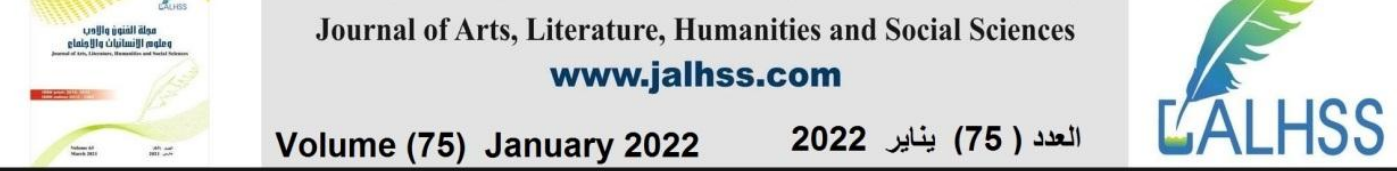

\section{Appendix 2:}

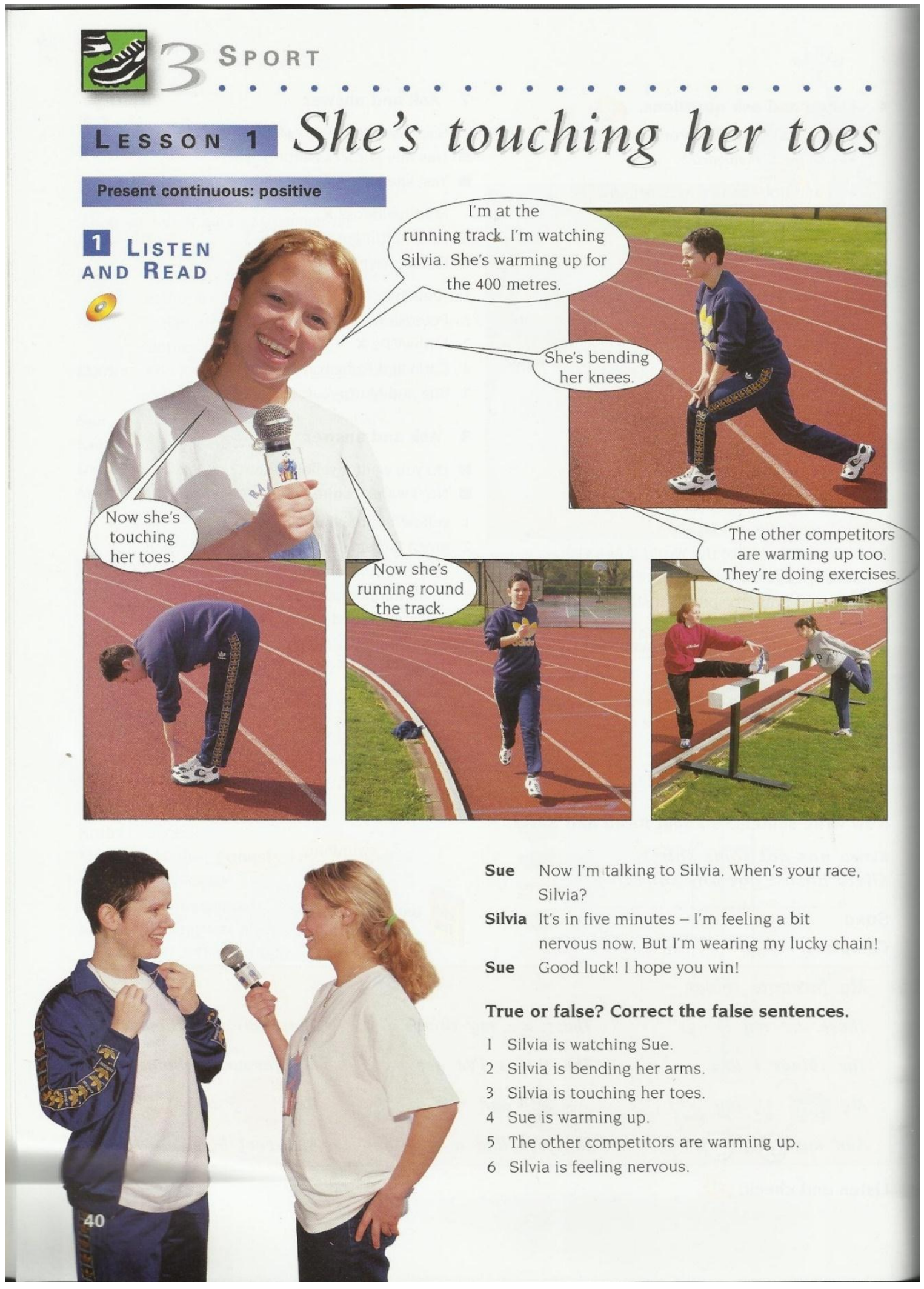




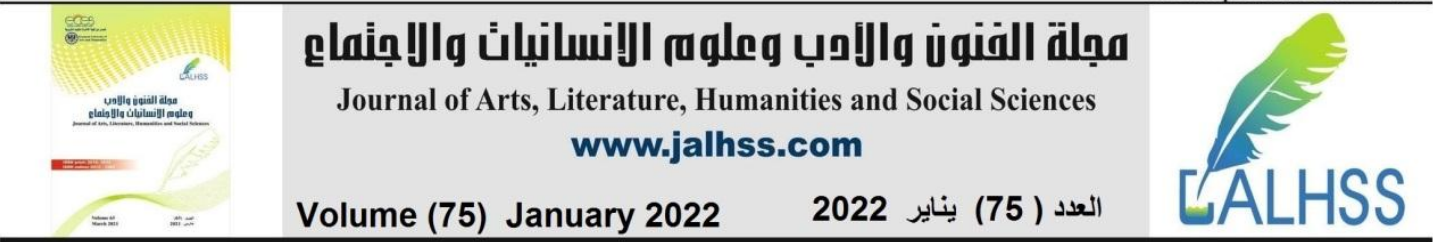

\section{GRAMMAR FILE}

Copy and complete. Choose words from the box.

\section{watching are $I^{\prime} \mathrm{m}$ \\ Present continuous}

Positive

Contractions

I am watching

you _ watching

he/she/it is watching

we/you/they _ watching

_ watching

you're watching

he's/she's/it's

we're/you're/they're

Listen and check.

Unit 3 Lesson 1 Activities 1 and 2

\section{GAME}

The Face Game

No, you aren't

I'm touching my eary

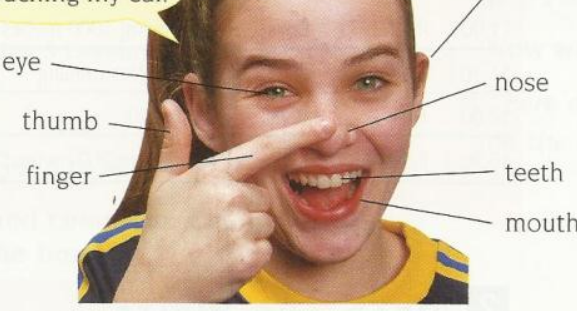

Unit 3 Lesson 1 Activity 3

REA D

Look at the photo of Kawa. Read and match the words with the numbers.

back chest feet hand head leg

Kawa has got short black hair and brown eyes. He is wearing a blue cap on his head. He is holding a volleyball in his left hand. His right hand is touching his right leg. He is wearing a T-shirt with number 8 on his back and WYG on his chest.

$\mathrm{He}$ is wearing white trainers on his feet.

Listen and check.

\begin{tabular}{ll}
\hline LOOKI & \\
\hline Singular & Plural \\
foot & feet \\
tooth & teeth
\end{tabular}

Unit 3 Lesson 1 Activities 4 and 5

\section{SOUND FILE}

Listen and repeat. (C)

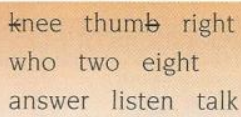

Now cross out the silent letters.

\section{WRITE}

Write about yourself.

I've got long black hair and brown eyes. I'm wearing a white shirt and black jeans. Who am I?

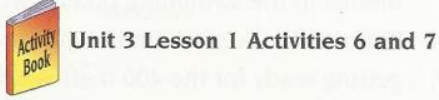

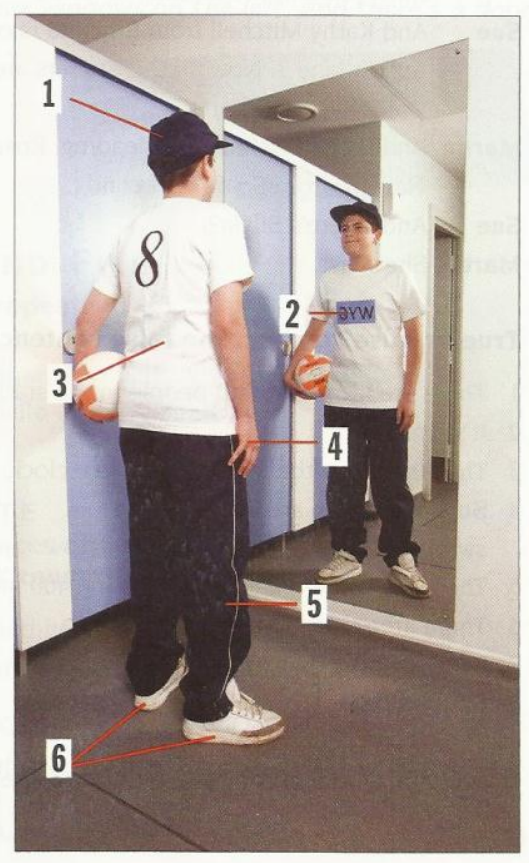




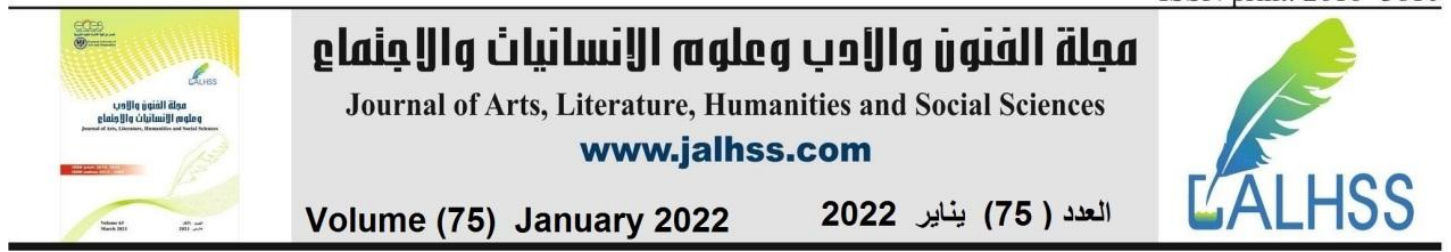

\section{Appendix 3:}

\section{S P ORT}

Lesson 2 She's on the left, in lane 3

There is/are. Prepositions of place: in, on

\section{Listen AND READ}

Sue Welcome to the Games! There are fifteen thousand people in the stadium today!

Martin The sun is shining and we're having a great time.

Sue Lots of things are happening today. At two o'clock there's a basketball game in the hall.

Martin And the boys are swimming the 1000 metres in the swimming pool now.

Sue But here in the stadium the girls are getting ready for the 400 metres running.

Martin There are some great competitors in the race. The favourite is Silvia Rossi from Italy. She's in the middle, in lane 2.

Sue And Kathy Mitchell from England is on the left, in lane 3. Now all the runners are waiting for the start

Martin And they're off! Kathy is leading, Rosa Navarro from Spain is second

Sue And where's Silvia?

Martin She's last.

True or false? Correct the false sentences.

1 There are fifty thousand people in the stadium.

2 It's a nice day.

3 There's a basketball game at three o'clock.

4 Sue and Martin are watching the swimming.

5 There are some great runners in the 400 metres

6 There aren't any boys in the race.

7 There isn't a Spanish runner in the race.

8 Silvia is playing basketball.

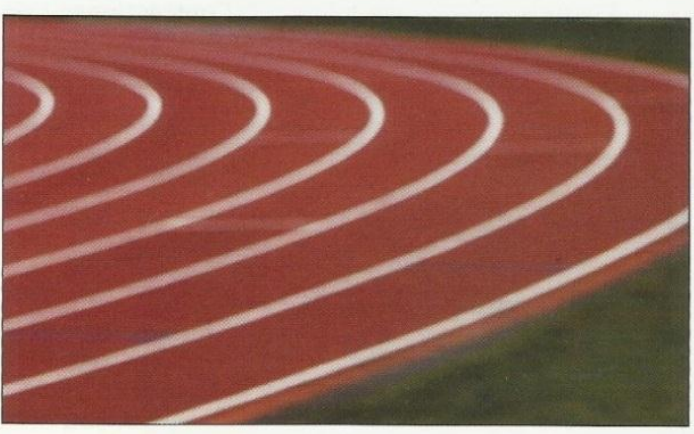

- World Youth Games • Events List

\begin{tabular}{llll}
11.00 & Pool & Boys & Swimming 1000 metres \\
\hline 11.30 & Stadium & Girls & 400 metres running \\
\hline 14.00 & Hall & Boys & Basketball \\
\hline 15.30 & Pool & Girls & Swimming 200 metres \\
\hline
\end{tabular}

2 READ AND WRITE Look at the Events List.

1 When is the 1000 metres swimming It's at 11 o'clock.

2 When is the 400 metres? It's is the basketball?

at 2 o'clock.

4 the 200 metres swimming?

Unit 3 Lesson 2 Activity

Now listen and find out the results of the race. 


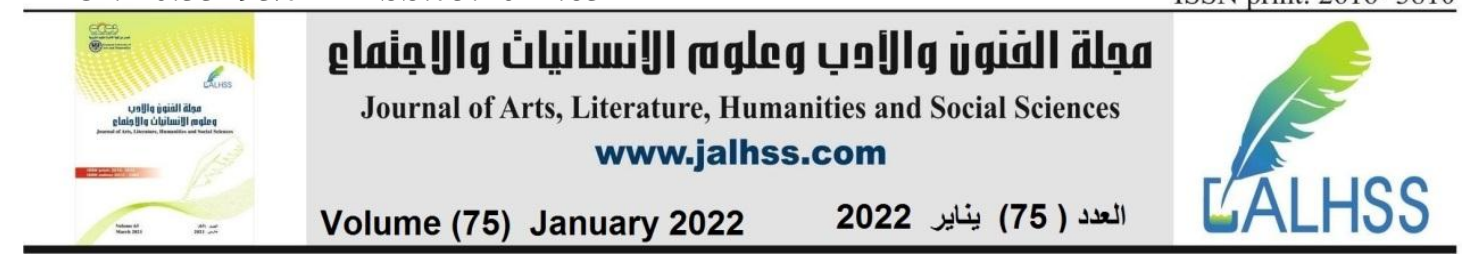

\section{SPEAK}

Look at the photo of the competitors' room. Which items can you see?

apple

books

chair

girls

magazine

table

television

bananas
boys
football
guitar
sandwiches
telephone
windows

There's a magazine.

There isn't a table.

There are some windows.

There aren't any sandwiches.

Unit 3 Lesson 2 Activity 2

\section{Grammar File}

Copy and complete. Choose words from the box.

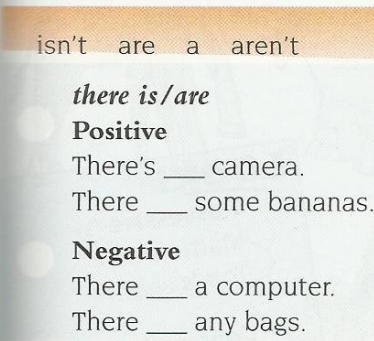

Listen and check.

Unit 3 Lesson 2 Activity 3

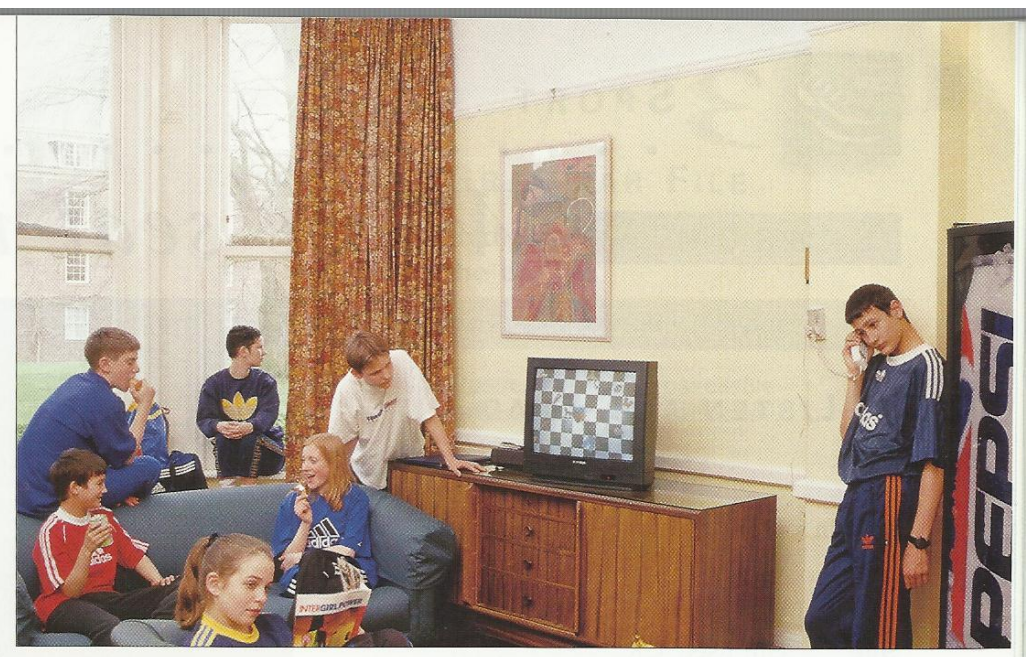

5 SPEAK AND WRITE

Look at the photo. Where are these things? Ask and answer.

drinks machine picture magazine

telephone television windows

Where's the picture?

It's on the wall.

Now write sentences about your classroom.

There are four windows on the left, and there's a door on the right ...

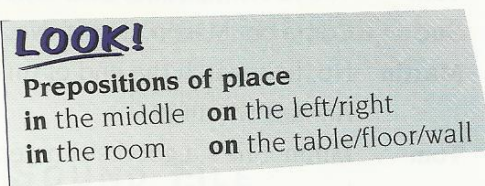

6 SOUND FILE

Listen and repeat.

$$
\begin{aligned}
& \text { today apple football machine middle } \\
& \text { picture hello table sandwich guitar }
\end{aligned}
$$

7 WRITE

Write sentences about the people in the competitors' room. Use these words.

$\begin{array}{llll}\text { sitting } & \text { standing } & \text { watching } & \text { opening } \\ \text { talking } & \text { drinking } & \text { eating } & \text { reading wearing }\end{array}$

Daniel and Kathy are talking. Daniel is drinking a coke and Kathy is eating an ice cream. 